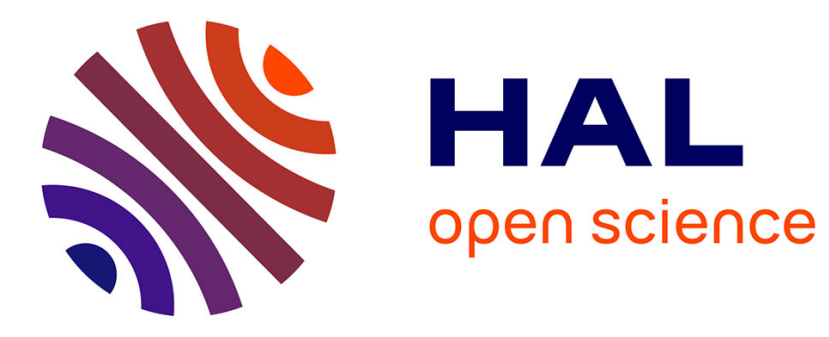

\title{
Rural waste disposal issues within urban borders
}

Florin Constantin Mihai, Corneliu Iatu, Adrian Grozavu

\section{To cite this version:}

Florin Constantin Mihai, Corneliu Iatu, Adrian Grozavu. Rural waste disposal issues within urban borders. 18th International Multidisciplinary Scientific GeoConference on Ecology, Economics, Education and Legislation SGEM 2018, Conference Proceedings, Jun 2018, Albena, Bulgaria. pp.761 768. hal-01838486

\section{HAL Id: hal-01838486 https://hal.science/hal-01838486}

Submitted on 13 Jul 2018

HAL is a multi-disciplinary open access archive for the deposit and dissemination of scientific research documents, whether they are published or not. The documents may come from teaching and research institutions in France or abroad, or from public or private research centers.
L'archive ouverte pluridisciplinaire HAL, est destinée au dépôt et à la diffusion de documents scientifiques de niveau recherche, publiés ou non, émanant des établissements d'enseignement et de recherche français ou étrangers, des laboratoires publics ou privés. 
Preprint version_Citation: Mihai, FC., latu C., Grozavu., A., 2018. Rural waste disposal issues within urban borders. 18th International Multidisciplinary Scientific GeoConference on Ecology, Economics, Education and Legislation SGEM 2018, Conference Proceedings, vol.18, Issue 5.1 pp.761-768

\title{
RURAL WASTE DISPOSAL ISSUES WITHIN URBAN BORDERS
}

\author{
Dr. Florin-Constantin Mihai ${ }^{1 *}$ Prof. Dr. Corneliu Iatu ${ }^{2}$ Prof. Dr. Adrian Grozavu ${ }^{2}$ \\ ${ }^{1}$ Department of Research, Faculty of Geography and Geology, Alexandru Ioan Cuza University \\ of Iasi, Romania Contact: mihai.florinconstantin@gmail.com \\ 2 Department of Geography, Faculty of Geography and Geology, Alexandru Ioan Cuza \\ University of Iasi, Romania
}

\begin{abstract}
The paper examines the waste management issues in the villages annexed to administrative-territorial units of the Romanian cities which have been frequently neglected by urban waste operators. The lack of waste collection services in such periurban communities favored the illegal waste disposal practices particularly prior to EU accession. The extension of waste collection services from main cities to such areas is compulsory in order to mitigate the environmental risks and the public health threats. The paper estimates the amounts of household waste susceptible to be uncontrolled disposed of by peri-urban villages in different geographical areas of North-East region with a particular focus on Neamt county. The paper points out that these rural settlements should receive the same attention concerning the municipal waste management services as the main urban areas. Traditional recovery of waste fractions at the household level (e.g., home composting) should be further promoted in such areas in order to avoid illegal dumping issue and to prevent the landfill of biodegradable waste as requested by EU regulations.
\end{abstract}

Keywords: waste management, illegal waste dumping, peri-urban areas, pollution

\section{INTRODUCTION}

Municipal waste management systems pose serious challenges across the globe and they must be continually improved in order to avoid pollution and threatening public health [1]. Population access to sound waste management services is still limited in developing and transition countries, particularly in their rural areas [2]. Villages are dealing with serious improper waste disposal practices such as open dumping or open burning of household waste [3]. Local administrative units (LAU) of cities may include one or several villages. These areas are susceptible to unsound waste management practices because there are usually neglected by urban waste operators and receive less attention from urban authorities[4]. This situation prevailed in Romanian urban areas, especially prior to EU accession. The expansion of waste collection coverage across the cities of North-East region is significant compared to 2003, but gaps in waste collection systems are detected in the case of villages annexed to urban areas [5]. The paper reveals the amounts of household waste susceptible to uncontrolled disposal in such areas during 2004-2015. 


\section{MATERIALS AND METHODS}

The North-East Region of Romania comprises six counties (Suceava, Neamt, Bacau, Botosani, Iasi, and Vaslui) with a total population of 3,302,217 according to the last population census (2011). There are 46 urban areas in the region, which include 119 villages in their administrative area. However, several major cities have no rural localities under their administrative area (Iasi, Suceava, Bacau, Botosani, Barlad, Roman, Husi, Campulung Moldovenesc, Radauti), therefore, they are excluded from the analysis. The number of such villages varies between one (eg. Parcovaci village - as part of Harlau city in Iasi county) and nine (eg. Haleasa, Lungeni, Neagra, Cotargasi, Darmoxa, Frasin, Holda, Holdita, and Pietroasa - as part of Brosteni town in Suceava county). The paper estimates the amounts of household waste uncontrolled disposed $\left(Q_{u d}\right)$ for each village included in the local administrative area of the city (LAU 2 level) within the North-East Region. The data are mapped at an urban LAU1 level which is equivalent to NUTS4 regions (http://ec.europa.eu/eurostat/web/nuts/localadministrative-units).

The time scale analysis is broken down into two main different periods, such as: 1) The period 2004-2009, in which smaller urban areas lack of formal waste collection services, and the population of the main cities is partially covered by such services while the rural localities included in their LAU are neglected by waste operators and household waste are improperly disposed on the surroundings. Several communes had been declared towns during 2003-2004 (eg. Roznov, Podu Iloaiei, Murgeni, Stefanesti, Flamanzi, Vivocu de Sus) despite the lack of basic utilities such as adequate sanitation facilities and waste management services. In this context, an evaluation for 2004 is performed where the ratio of inhabitants in such villages of total LAU population is determined. 2) The period 2010-2015, which is characterized by the expansion of urban waste collection coverage at regional level following the closure of local dumpsites from smaller urban areas and rural municipalities, but with a low collection efficiency outside the core-urban area.

The indicator mentioned above was calculated using the following relation if there are no waste collection services across villages as in the first stage [5]:

$\mathrm{Q}_{\mathrm{ud}}=\left\{\mathrm{Q}_{\mathrm{wu}}-\left[\left(\mathrm{Q}_{\mathrm{wu}}-0.4 * \mathrm{Q}_{\mathrm{bw}}\right)+\left(\mathrm{Q}_{\mathrm{wu}}-0.1 * \mathrm{Q}_{\mathrm{r}}\right)\right]\right\}$

$\mathrm{Q}_{\mathrm{wu}}=$ waste uncollected by formal waste management services (waste operators), which is calculated according to the formula:

$\mathrm{Q}_{\mathrm{wu}}=\mathrm{P} * \mathrm{~W}_{\mathrm{g}} * 365 / 1000, \mathrm{P}-$ population of the village (noWCS scenario)

$\mathrm{W}_{\mathrm{g}}$ - per capita waste generation rate $=0.3 \mathrm{~kg}$.inhab. $\mathrm{yr}^{-1}$ (Population Census 2002 data for time series: 2004-2009) and 0.33 kg.inhab.day ${ }^{-1}$ (Population Census 2011 data for time-series 2010-2015). The per-capita waste generation rate is below the national flat rate $\left(0.4\right.$ kg.inhab.day $\left.{ }^{-1}\right)$ as stipulated by National Waste Management Plan (NWMP) due to poorer socioeconomic features of the study area [6].

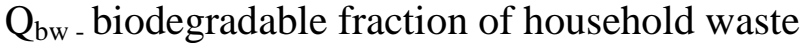

$\mathrm{Q}_{\mathrm{r}-\text { recyclables (metals, paper and cardboard, plastics, glass, wood) }}$

The data for these fractions are extracted from the amounts of waste uncollected $\left(\mathrm{Q}_{\mathrm{wu}}\right)$ using a rural municipal waste composition provided by the regional waste management plan [7] applied for the 2004-2009 period, and data determined by Ingleziakis et al. for the period 2010-2015 [8]. Waste collection efficiency may differ from one county to another and there may be disparities between cities within the same region [9]. 
Recycling and recovery practices at individual household level prevent or mitigate the uncontrolled waste disposal practices. In China, some villages used biogas ecological cycle technology to dispose of organic waste ( $80 \%$ of household waste) as a source of bionergy for rural residents [10]. The national waste management plan from Poland stipulates that part of the volume of biodegradable waste generated, particularly in villages and smaller towns, is utilized by the inhabitants on their own [11]. Home composting and animal feed account $15 \%$ of total biowaste generated in smaller towns [11]. In Romania, the ratio of biodegradable waste is higher of total municipal waste fraction, particularly in smaller urban areas and rural municipalities (communes). In this context, a factor of 0.4 is used to calculate the biowaste generated and uncollected across rural localities included in the urban LAU and 0.1 for recyclables. The magnitude of home composting and animal feed practices are considered lower in such villages compared to other distant rural municipalities where agricultural activity is more intense.

Currently, all urban areas of North-East Region are served by public or private waste operators. However, field observations, sanitation campaigns, and mass-media points out that such villages are still being exposed to illegal waste disposal practices. There is no waste management data at such level and the model use a low collection efficiency (Cef) of $40 \%$ (WCS40) to calculate the amounts of waste uncontrolled disposed in the second stage (2010-2015) as follows: $\mathrm{Q}_{w u}=\mathrm{Q}_{\mathrm{wu}}\left(\right.$ noWCS) - $\mathrm{Q}_{\mathrm{wu}}($ noWCS) $*$ Cef.

The data combined from the main two periods reveal the amounts of household waste uncontrolled disposed of by such villages across 12 years.

The paper performs a comparative analysis of the amounts of household waste uncontrolled disposed by such villages and those volumes reported to be eliminated in open dumps. The volume data are transformed into tons using a specific density of 400 $\mathrm{kg} / \mathrm{m}^{3}$ in case of rural dumps. The data are provided by local environmental authorities, but there are available only for 20 out 119 villages included under urban LAU (see table $1)$.

\section{RESULTS AND DISCUSSION}

Several rural municipalities (communes) were declared towns during 2003-2004 despite the lack of proper infrastructure, specifically in urban areas including a sound waste management system. Such localities cover several villages in their administrative area which may count over $40 \%$ of the total urban LAU population. Statistically, they are included as urban population (LAU 1 level) and only population censuses provide demographic data at the village level (LAU 2 equivalent to NUTS 5 regions). There are 118 rural localities included in administrative areas of cities or towns which had counted 116992 inhabitants based on Population Census data from 2002. The left map of figure 1 shows that most of "urban population" of several towns (LAU) lived basically in such villages without access to basic utilities. There are towns where over $60 \%$ of the population live in the villages annexed to their administrative areas such as Stefanesti (77\%, Botosani county), Dolhasca and Salcea towns (67\%, Suceava county), Brosteni (65\%, Suceava county), Flamanzi (61\%, Botosani county). 
More than 3 villages are found under the administrative area of cities and towns as follows: Brosteni (9 villages), Dolhasca (7 villages), Bicaz, Murgeni, Negresti (6 villages) Vaslui, Pascani, Darmanesti, Saveni, Liteni (5 villages), Flamanzi, Stefanesti, Salcea, Podu Iloaiei (4 villages). The poor waste management facilities prevail outside the main urban area, particularly in the first stage (2004-2009). This fact is also supported by the dumpsites counted by local environmental authorities which should have been closed until 16 July 2009. In 2004, the amount of household waste uncontrolled disposed of by villages under the urban administrative area was $9332.54 \mathrm{t}$ which means 55995.24 t during 2004-2009 (6 years).

The maximum value is 769 t.yr $^{-1}$ (Pascani city) followed by Dolhasca (596.28 t.yr ${ }^{-1}$ ) and Flamanzi (575 t.yr $\left.{ }^{-1}\right)$. Significant amounts of household waste uncontrolled disposed (300-500 t.yr) were estimated in case of Brosteni, Liteni, Salcea (Suceava county), Darmanesti (Bacau county), Stefanesti (Botosani county), Vaslui, Murgeni (Vaslui county). Such urban areas must expand the waste collection services to surrounding villages to avoid serious pollution threats. Most of the urban areas are responsible for $100 \mathrm{t}$ of solid waste dumped into the environment each year with the exception of Gura

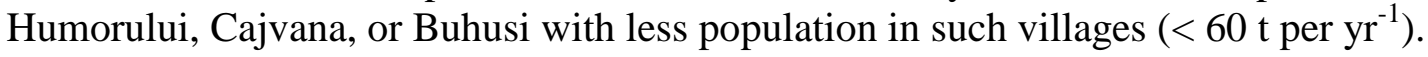

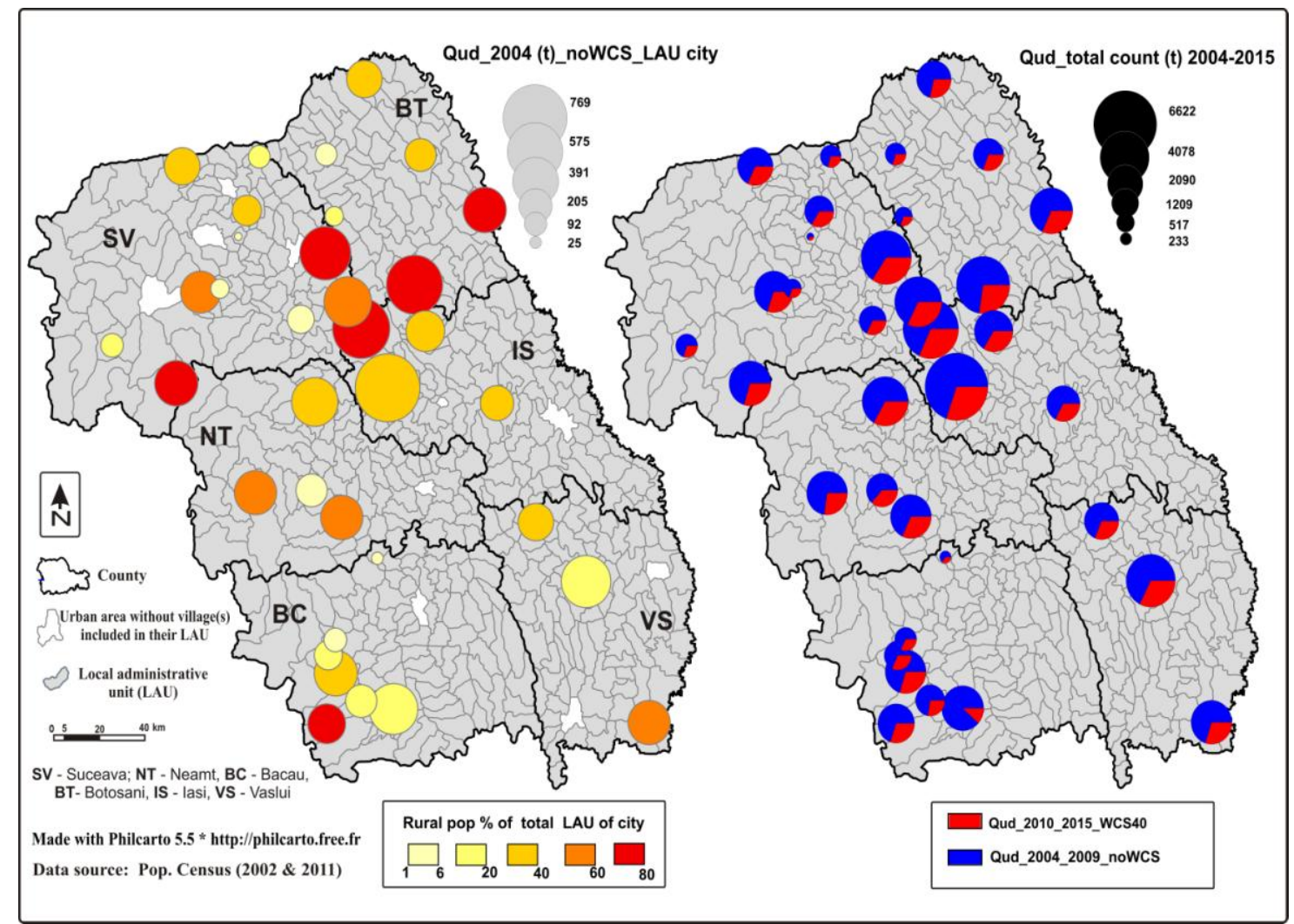

Figure 1. Estimation of household waste uncontrolled disposed in villages annexed to urban administrative areas (LAU 1) across the North-East Region of Romania

In 2011, the number of inhabitants which lived in the villages under the urban administration was 104393 according to the last Population Census with 12599 inhabitants less than the previous census (2002). This demographic decline is explained by living the country by people looking for work abroad, mainly in EU (e.g. Spain, Italy). 
North-East of Romania is a poor and a peripheral EU region, which needs access to a proper road infrastructure (better roads maintenance, highways, high-speed railways) to improve connection to West (EU) and South (Bucharest capital city) and to stimulate massive investments in the region. Significant socioeconomic disparities are found across North-East region between the largest cities (Iasi, Suceava, Bacau, Piatra Neamt) and smaller towns with strong rural features (Flamanzi, Stefanesti, Roznov, Salcea, Milisauti, Liteni, Dolhasca, Murgeni) [12]. In the latter case, full coverage of population to waste collection services is problematic and illegal disposal practices are still visible on the field.

Eu funds have improved waste management infrastructure across several counties, but delays in the construction process (waste collection platforms, sanitary landfills, sorting and composting stations, transfer stations) lead to illegal waste disposal practices on peripheral urban areas. In fact, the waste management service may be available to 100 percent of the city, but perhaps only 80 percent actually use that service [4]. The rural localities within urban borders are at risk of being neglected by sound waste management services compared to the main urban area. Same discrepancies are revealed in Varna (Bulgaria) where full coverage ends at the city limit and city's 5 villages (included in the urban administrative area) are each served with a single container that is collected once per month if at all [4]. Thus, such villages receive less attention from urban authorities in terms of waste collection schemes which further expose the local population to illegal dumping practices.

For the second period (2010-2015), the paper estimates 24648.5 to be uncontrolled across rural localities included in the urban local administrative units or $4108 \mathrm{t}$ per yr with a collection efficiency set up to $40 \%$. The right map of figure 1 reveals the critical period during 2004-2009 compared to 2010-2015 when waste collection services have begun to emerge. The total amount of household waste uncontrolled disposed of by the all 119 villages under the urban administration is $80643.74 \mathrm{t}$ during 12 years (20042015). Such values vary from $6622 \mathrm{t}$ (Pascani urban LAU) towards less than $1000 \mathrm{t}$ and highlight the fact that such villages may be a significant pollution source at local level. This fact is demonstrated by illegal dumping practices observed across Neamt County as shown in figure 2 .

The larger cities (Piatra-Neamt, Roman, Targu Neamt) provide a proper waste collection within the main urban area and the wastes collected were disposed into urban landfills, while neighboring villages have problems with the waste management sector. The worse situation characterized the smaller urban areas in the first stage. Roznov town was not served by a formal waste collection services until 2010 and Bicaz city had an obsolete waste management infrastructure. In the latter case, seven dispersed mountain villages make more difficult to provide a coherent waste collection system without proper funds. The poor coverage of such villages (which are under the urban administration) to reliable waste management services suggests a poor urban governance across the North-East region.

Despite the lack or poor waste management facilities during 2004-2010, only 20 villages (out of 119) have data concerning the surface (ha) and volumes of dumpsites which are ultimately transformed into tons. These dumpsites cover almost 10 ha being disposed of $28928 \mathrm{t}$ compared to $8098 \mathrm{t}$ estimated to be uncontrolled disposed in the first stage which represented almost $28 \%$. 


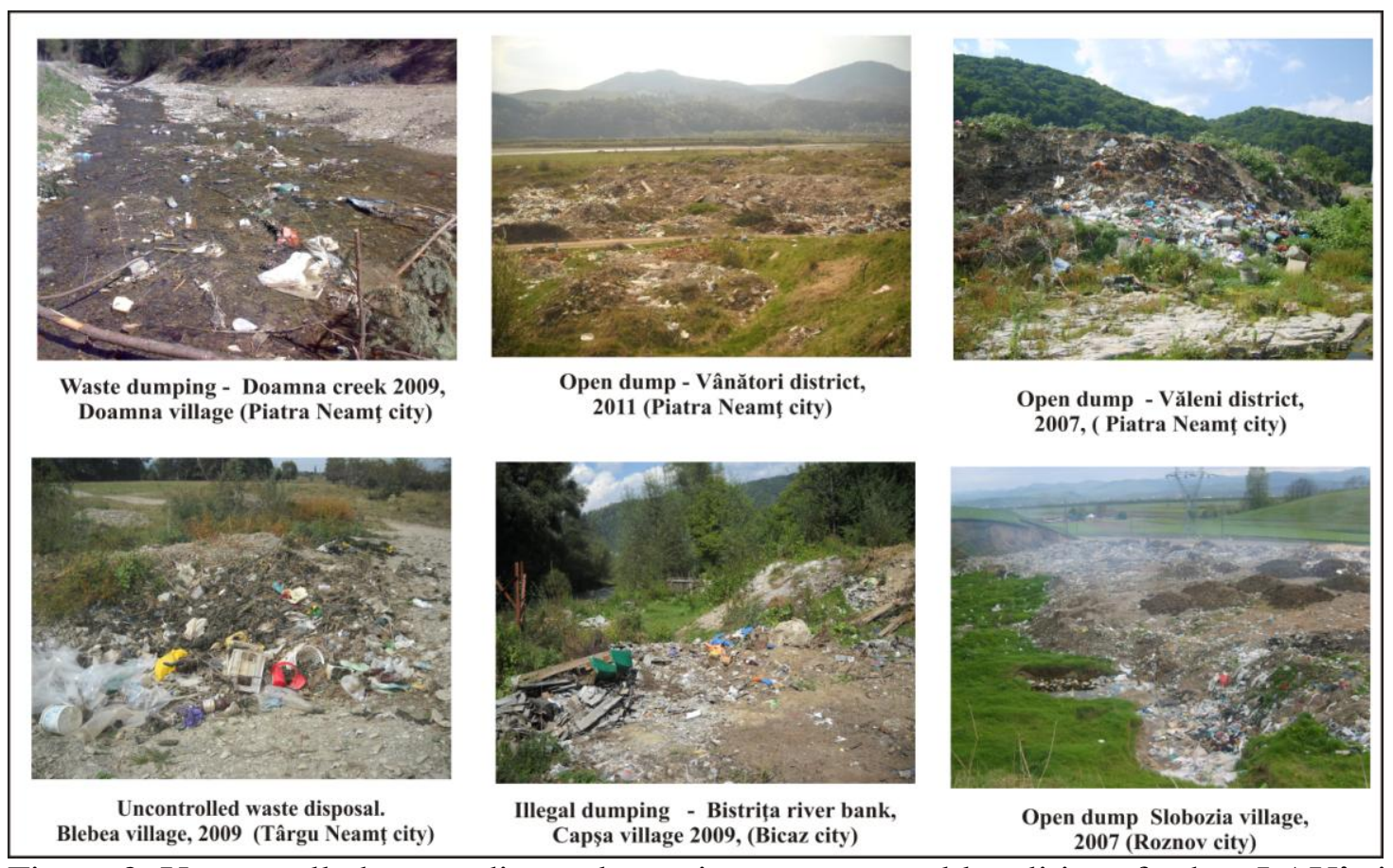

Figure 2. Uncontrolled waste disposal practices across rural localities of urban LAU's in Neamt county

Data concerning the rural dumpsites have a poor geographical coverage and their reliability depends on local authority involvement and honesty. As an example, there is no data concerning dumpsites in the villages of urban LAU's across Neamt county despite clearly evidences shown in figure 2. Also, some dumpsites are temporary (exposed to floods or they are burnt) which are not comprised by statistics. The data broken down per village reveal several situations as shown in table 1: (i) the largest dumpsite is reported in Bobulesti village (1.6 ha - $3400 \mathrm{t})$ with a direct estimated contribution of $680.61 \mathrm{t}$ (ii) the largest amount disposed is $8000 \mathrm{t}$ in Bohoghina village (1ha) despite a low contribution of village $(85.67 \mathrm{t}$ ) (iii) the smallest dumpsite is reported in Nicolae Balcescu village ( 0.01 ha with $80 \mathrm{t}$ ) despite a direct contribution of $1912.3 \mathrm{t}$ (iv) the lowest amount of waste disposed - $40 \mathrm{t}$ in Carja village despite a direct contribution of $579 \mathrm{t}(\mathrm{v})$ similar values between amount of waste disposed $(400 \mathrm{t})$ and direct contribution (439.86 t) in case of village Valea Mare (vi) same area reported (0.4 ha) for all villages of Negresti LAU (vii) dumps with same area may have different volumes and viceversa. The above situations point out that assessment of illegal waste disposal practices is a complex task and it is poorly covered by official statistics. Generally, the amounts waste disposed in dumps are expected to be larger than those estimated as direct contributions by villages because there may be other inputs to take into consideration besides local residents such as economic agents, illegal traffic of waste from the main urban area, leisure activities etc. Dumpsites data for six villages are significantly below than those estimated and the other hand, in some cases, there are huge differences between these data. Economic agents (local or regional) that do not sign contracts with waste operators (although they are obliged by law) may significantly contribute to the illegal dumping practices (household and packaging waste, demolition and construction) on improper sites in the outskirts of cities. Furthermore, the expansion of waste collection services towards rural areas attached to urban LAU's cities have been partially achieved, especially in recent years. 
Table 1. Rural dumps vs amounts of household waste uncontrolled disposed

\begin{tabular}{|c|c|c|c|}
\hline $\begin{array}{c}\text { Village _ part of urban } \\
\text { LAU_county }\end{array}$ & S (ha) & $\mathrm{Q}(\mathrm{t})$ & $\begin{array}{c}\text { Qud_2004_2009_ } \\
\text { noWCS }(\mathrm{t})\end{array}$ \\
\hline \multicolumn{4}{|l|}{ MURGENI (LAU)_VS } \\
\hline Carja & 0.02 & 40 & 578.19 \\
\hline Floreni & 0.05 & 100 & 306.80 \\
\hline Latesti & 0.04 & 80 & 192.89 \\
\hline Raiu & 0.5 & 1000 & 344.61 \\
\hline Sarateni & 0.04 & 80 & 213.95 \\
\hline Schineni & 0.03 & 60 & 294.84 \\
\hline \multicolumn{4}{|l|}{ NEGRESTI (LAU)_VS } \\
\hline Cazanesti & 0.4 & 800 & 219.21 \\
\hline Glodeni & 0.4 & $\ldots$ & 143.59 \\
\hline Parpanita & 0.4 & 800 & 289.57 \\
\hline Poiana & 0.4 & 400 & 132.10 \\
\hline Valea mare & 0.4 & 400 & 439.86 \\
\hline \multicolumn{4}{|l|}{ PODU ILOAIEI (LAU)_IS } \\
\hline Budai & 0.5 & 1600 & 448.96 \\
\hline Cositeni & 0.2 & 48 & 154.60 \\
\hline Scobalteni & 1 & 4000 & 496.82 \\
\hline \multicolumn{4}{|l|}{$\begin{array}{l}\text { STEFANESTI (LAU)_BT } \\
\end{array}$} \\
\hline Badiuti & 1.2 & 3040 & 425.50 \\
\hline Bobulesti & 1.6 & 3400 & 680.61 \\
\hline Stanca & 1.3 & 3000 & 444.17 \\
\hline \multicolumn{4}{|l|}{ FLAMANZI (LAU)_BT } \\
\hline Nicolae balcescu & 0.01 & 80 & 1912.13 \\
\hline Chitoveni & 0.5 & 2000 & 293.88 \\
\hline \multicolumn{4}{|l|}{ BUCECEA (LAU)_BT } \\
\hline Bohoghina & 1 & 8000 & 85.67 \\
\hline
\end{tabular}

Source: Local Environmental Protection Agencies and author calculations

\section{CONCLUSION}

Full population coverage throughout the urban local administrative units is a basic requirement for the implementation of a proper and efficient waste management system which significantly decrease the exposure of villages to illegal dumping practices. The paper reveals that all 119 villages included in the urban LAU's are responsible for dumping 80643.74 t during 12 years (2004-2015) with a critical situation during 20042009 characterized by the lack of waste collection services and widespread improper disposal practices. Good urban governance requires equitable access to basic utilities across all settlements under administration. Municipal waste management system must be continually adapted to the factors that favor urban LAU development by implementing selective collection facilities, better home composting practices in order to support sustainable programs for waste recovery and waste diversion from landfills. The responsibility and receptivity of citizens to such programs will play an important role in the sustainability of this process which finally will improve the quality of life.

\section{ACKNOWLEDGEMENTS}

This work was supported by a grant of the "Alexandru Ioan Cuza" University of Iasi, within the Research Grants program, Grant UAIC, code GI-UAIC-2017-06 


\section{REFERENCES}

[1] Hoornweg, D., Bhada-Tata, P. What a waste: a global review of solid waste management. Urban Development Series Knowledge Papers, World Bank, Washington D.C. 2012

[2] Han, Z., Liu, Y., Zhong, M., Shi, G., Li, Q., Zeng, D., Zhang, Y., Fei, Y., Xie, Y. Influencing factors of domestic waste characteristics in rural areas of developing countries. Waste Management, vol. 72, pp. 45-54, 2018

[3] Taboada-González, P., Armijo-de-Vega, C., Aguilar-Virgen, Q., Ojeda-Benítez, S. Household Solid Waste Characteristics and Management in Rural Communities. The Open Waste Management Journal, vol. 3, pp. 167-173, 2010

[4] Scheinberg, A., Wilson, D.C., Rodic, L. (eds.). Solid waste management in the world's cities. The third edition in UN-Habitat's State of Water and Sanitation in the World's Cities Series. Published by Earthscan for UN-Habitat, March 2010

[5] Mihai, F.C. Territorial disparities in municipal waste management. Case study: Neamt County. Ph.D. Thesis. Department of Geography, Faculty of Geography and Geology, „Alexandru Ioan Cuza” University of Iasi, 2013.

[6] National Waste Management Plan (version 5, 2 November 2017), http://mmediu.ro/app/webroot/uploads/files/PNGD_vers5.pdf (Accessed on 14 January 2018, in Romanian).

[7] Regional Environmental Protection Agency of Bacau 2006. Regional waste management plan of North East Region [in Romanian]

[8] Inglezakis, V., Dvorsak, S., Varga, J., Venetis, C., Zorpas, A., Eliopoulos, K., Ardeleanu, N., Ilieva, L., Moustakas, K., Loizidou, M., Cobzaru, C. Municipal solid waste experimental studies in Romania and Bulgaria, Int. J Chem Environ Eng Syst (IJCEES), vol. 3(3), pp. 64-73, 2012

[9] Wilson, D.C., Rodic, L., Cowing, M.J., Velis, C.A., Whiteman, A.D., Scheinberg, A., Vilches, R., Masterson, D., Stretz, J., Oelz, B. 'Wasteaware' benchmark indicators for integrated sustainable waste management in cities, Waste Manage., vol. 35, pp. 329342, doi: 10.1016/j.wasman.2014.10.006, 2015.

[10] Wang, A., Zhang, L., Shi, Y., Rozelle, S., Osborn, A., Yang, M. Rural Solid Waste Management in China: Status, Problems, and Challenges. Sustainability, vol. 9, 506, doi:10.3390/su9040506, 2017

[11] Poland - The 2010 National Waste Management Plan - December 2006, https://www.mos.gov.pl/g2/big/2009_06/e97e2a07ce29b48c19f462f83a6bf1a9.pdf

[12] ADR Nord-Est 2013 Regional Development Strategy of North-East 2014-2020, http://www.adrnordest.ro/user/file/pdr/v3/strategie\%20RNE\%2020142020\%20aprilie\%202013.pdf (Accessed on 20 March 2018, in Romanian). 